\title{
Thermodynamic Analysis of Behavior in Combined Cycles Operating with Biogas and Municipal Solid Waste
}

\author{
A. Gallego, H. Kubo, A. C. Gutierrez-Gomez, R. P. Bereche, A. P. Neto, A. D. Rocha \\ Federal University of ABC, Santo André, Brazil \\ E-mail: a.gallego@ufabc.edu.br, carolkubo@gmail.com, andrea.gutierrez@ufabc.edu.br, \\ reynaldo.palacios@ufabc.edu.br, ana.neto@ufabc.edu.br, a.damiani@ufabc.edu.br
}

Received 20 December 2018, Revised 30 April 2019, Revised 02 May 2019, Accepted 02 May 2019

\begin{abstract}
The use of biogas from landfills, and Municipal Solid Waste (MSW) as fuel has an important role in the context of electricity generation and environmental protection. The use of MSW as fuel to produce electricity has the advantage to reduce the use of landfills, which are responsible for problems such as space loss and sanitation that large cities have to deal with. However, the MSW and biogas available in landfills have been used individually to generate power. Among the main technologies of thermal conversion of MSW, incineration is the most common, and it is presently used in huge-sized facilities in the world, but when the MSW flows are lower, the use of an incineration system is not justified; therefore, the gasification technology is recommended. In this work a combined cycle composed of an internal combustion engine burning biogas, with a gasification system of MSW combined with a system to burn the syngas to produce steam and operate in a steam Rankine cycle, and an organic Rankine cycles was proposed, modelled and simulated. The average value of the exergetic efficiency obtained in the simulations was $15.2 \%$, and the average net power obtained from the combined cycle was $3,112 \mathrm{~kW}$. The participation of the Engine cycle in the net power of the Combined Cycle was $39.1 \%$, while the Steam Rankine cycle participation in the Combined Cycle was 53.\%, owing to the high consumption of auxiliaries, the variation of the heating value, and the biogas consumption in the combustion, with an average efficiency of $11.1 \%$. The organic Rankine cycle contributed, on average, in $6.9 \%$ to the total power. The average amount of $\mathrm{CO}_{2}$ emitted obtained in the simulation was $1,969 \mathrm{~g} / \mathrm{kWh}$. Regarding the avoided $\mathrm{CH}_{4}$ emissions, an average of $91.5 \mathrm{~g} / \mathrm{kWh}$ was obtained.
\end{abstract}

\section{Keywords: Municipal Solid Waste, Biogas, Energy Conversion, Thermodynamic Analysis.}

\section{Aims and Scope}

With advances in technology over the last decades and the trend towards a sustainable model bound to lower environmental impacts, energy companies have invested in the development of renewable energy. The electric power generation plant from biogas and municipal solid waste (MSW) contribute to the decrease in the emissions of greenhouse gases (e.g., methane) when the wastes are put in inadequate places and without control as well as in the extension of the useful life of landfills.

To convert the landfills gases into useful energy are available some technologies like internal combustion engines, gas turbines, steam systems, and fuel cells. Most systems that supply electrical power from gases use internal combustion engines or turbines. In the United States of America, most of the installed systems, or in development, use internal combustion engines. The technologies for electric power generation in landfills in the USA represent $65.8 \%$ of these engines, while gas turbines represent $12.1 \%$, steam turbines $8 \%$, and micro turbines only $1 \%$ [1].

Regarding the thermal conversion of MSW, the most commonly used technology is incineration, although gasification and pyrolysis systems are also in operation. In Table 1 presents a comparative analysis between the thermal technologies of conversion of MSW, where is highlight the main products (syngas and heat), the reduction of volume
( $90 \%$ to $99 \%$ of volume), the operation temperature $\left(750^{\circ} \mathrm{C}\right.$ to $\left.1600^{\circ} \mathrm{C}\right)$, and the emissions $\left(\mathrm{CO}_{2} ; \mathrm{NO}_{\mathrm{x}}\right.$; Dioxin) [2].

Table 1. Comparison of Technologies using MSW

\begin{tabular}{|c|c|c|c|}
\hline Technology & Gasification & Incineration & Pyrolysis \\
\hline $\begin{array}{l}\text { First } \\
\text { Product }\end{array}$ & $\begin{array}{c}\text { Syngas (biomass } \\
\text { moisture }<15 \% \\
\text { is required) }\end{array}$ & Flue gas & $\begin{array}{l}\text { Fuel } \\
\text { Gases; } \\
\text { Syngas }\end{array}$ \\
\hline $\begin{array}{l}\text { Second } \\
\text { Product }\end{array}$ & $\begin{array}{l}\text { Fuels; Chemical } \\
\text { Components; } \\
\text { Electricity }\end{array}$ & $\begin{array}{l}\text { Heat; } \\
\text { Electricity }\end{array}$ & $\begin{array}{c}\text { Oil from } \\
\text { biomass; } \\
\text { Vegetal } \\
\text { Coal }\end{array}$ \\
\hline $\begin{array}{l}\text { Residual } \\
\text { Landfills }\end{array}$ & $\begin{array}{l}\text { Dust; Metals; } \\
\text { Slag }\end{array}$ & $\begin{array}{l}\text { Dust; Metals; } \\
\text { Slag }\end{array}$ & $\begin{array}{c}\text { Dust; } \\
\text { Metals; } \\
\text { Slag Char }\end{array}$ \\
\hline $\begin{array}{l}\text { Volume } \\
\text { Reduction }\end{array}$ & $\begin{array}{l}\text { Up to } 90 \% \text { of } \\
\text { Volume }\end{array}$ & $\begin{array}{l}\text { Until } 99 \% \text { of } \\
\text { volume }\end{array}$ & $\begin{array}{l}\text { Up to } \\
90 \% \text { of } \\
\text { Volume }\end{array}$ \\
\hline Temperature & $\begin{array}{l}\text { Maximum } \\
1200^{\circ} \mathrm{C} \\
\text { Reactor gas } \\
\text { outlet } 500^{\circ} \mathrm{C}\end{array}$ & $\begin{array}{l}\text { Minimum of } \\
750^{\circ} \mathrm{C} \\
\text { Maximum of } \\
1200^{\circ} \mathrm{C}\end{array}$ & $\begin{array}{l}300^{\circ} \mathrm{C}- \\
1600^{\circ} \mathrm{C}\end{array}$ \\
\hline Emissions & $\begin{array}{l}\mathrm{CO}_{2} ; \mathrm{CO} ; \mathrm{H}_{2} ; \\
\mathrm{CH}_{4} ; \mathrm{N}_{2} ; \text { Slag }\end{array}$ & $\begin{array}{c}\mathrm{CO}_{2} ; \mathrm{NO}_{\mathrm{x}} ; \\
\text { Dioxin; Dust }\end{array}$ & $\begin{array}{l}\text { Dust; } \\
\text { Slag }\end{array}$ \\
\hline
\end{tabular}

Concerning electricity generation efficiency, the study was performed to set Combined Cycles (hybrid cycles or 
Waste-to-Energy (WTE) plants) with different fuels. Some of this type of plants can be found in literature, for instance, [3] presents a plant that uses natural gas in a gas turbine with a heat recovery steam generator which is integrated to a waste incinerator using MSW as fuel. According to simulations performed by [3], the plant efficiency resulted in the range of 37 to $41 \%$, but it should be noted that 34 to $52 \%$ of the energy consumed by the plant comes from natural gas. Moreover, it is worth mention that this type of configuration is the most analyzed because of the scale of the incineration system because this technology is used in the conversion of large amounts of MSW. The use of gas turbine presents power output and efficiency compatible with the operation of the incineration system.

However, when the quantities of MSW are lower, the use of an incineration system is not justified; therefore the gasification technology is recommended. Taking into consideration the combined use of different fuels as presented by [3], the use of micro-turbines or small and medium-sized motors is more suitable. In order to improve the energy utilization of the plant, the use of Organic Rankine Cycle (ORC) can be considered, this way, the efficiency of the combined cycle can increase.

From the considerations previously presented, a Combined Cycle was developed in this work. This cycle was composed of an internal combustion engine type "LeanBurn" using biogas, a gasification system using MSW, an Organic Rankine cycle and a conventional Rankine cycle (steam power cycle), with the purpose to analyze and identify the efficiency and the power generation of this plant for different operating conditions. To analyze the behavior of the cycle, simulations were performed considering the MSW moisture content and biogas to syngas ratio variations. The reference condition was moisture $48.7 \%$, and biogas to syngas ratio used in the combustion chamber was $0 \mathrm{~kg}$ biogas to $\mathrm{kg}$ syngas. Then, for each biogas to syngas ratio $(0,0.10$ and $0.20 \mathrm{~kg}$ biogas to $\mathrm{kg}$ syngas the moisture content was set to $43.6 \%$ and $53.7 \%$.

\section{Thermodynamic Analysis \\ 2.1 System Description}

The Combined Cycle is shown in Figure 1, where the streams and equipment that compose the cycle can be observed. Biogas for engine and combustion chamber was used from landfill (Biogas source), in the reference, the condition was used 961 normal meters cubic per hour of biogas for the engine. The engine (I) consumes biogas; it flows through a biogas clean-up system $(\mathrm{H})$ and, if necessary, part of the biogas could be consumed in the combustion chamber (C) and air Heater (M). Biogas Cleanup System $(\mathrm{H})$ remove water and hydrogen sulfide $\left(\mathrm{H}_{2} \mathrm{~S}\right)$ from the biogas.

In MSW source were used 4 ton per hour of wastes with $48.66 \%$ of moisture content. The MSWs lows through a treatment system (A), and the MSW is dried, then the noncombustible materials as metal and glass are separated, and the final MSWs (combustible fraction) are crushed. In the output of the treatment system, the moisture content of MSWs is $10 \%$.

In the sequence, the treated MSW pass through a gasifier (B) which operates at $800^{\circ} \mathrm{C}$ where syngas is produced. The syngas is mixed with air and biogas (when necessary), then the mixture is to burn in the combustion chamber for the generation flue gases. The flue gases flow towards into the boiler and to produce steam $\left(6.5 \mathrm{MPa}\right.$ and $\left.450^{\circ} \mathrm{C}\right)$. Finally, the steam is used in Steam Rankine Cycle (SRC).

The Mixer (J) receives the flue gas from Biogas engine (I) and flue gas from heat recovery steam generator (D) and directs the mixture to the Organic Rankine Cycle Heat Exchanger (K). In this equipment, energy is transferred to the therminol 55. This fluid transfers energy to the Organic Rankine Cycle-ORC (L). The organic Rankine cycle was modeled from Turboden 6 data sheet. The combustion products from the device K (Organic Rankine Cycle Heat Exchanger) are routed to the Air Heater (M) and then, to the chimney.

Cooling water system is composed of cooling tower and water pump. The condenser $(\mathrm{F})$ and the condenser of the Organic Rankine Cycle (L) are cooled by a Cooling water System (composed of a cooling tower and the reposition water pump) (P).

\subsection{Component Analysis}

The equations for each of the components considering mass and energy conservation, exergy and entropy balances are presented below.

Overall mass balance:

$\left(\sum \dot{m}_{i}\right)_{\text {out }}=\left(\sum \dot{m}_{i}\right)_{\text {in }}$

where $\dot{m}$ is the mass flow rate and $\mathrm{i}$ the state point or equipment index.

Energy balance:

$\dot{Q}+\left(\sum \dot{m}_{i} h_{i}\right)_{\text {in }}=\left(\sum \dot{m}_{i} h_{i}\right)_{\text {out }}+\dot{W}$

where $\dot{Q}$ is thermal energy rate, $\mathrm{h}$ is specific enthalpy, $\dot{W}$ is the power energy rate.

Isentropic efficiency turbine ( $\eta_{\text {Turbine }}$ ): Eq. 3. (Turbine) and Eq. 4 (Pump, Fan and Compressor).

$\eta_{\text {Turbine }}=\frac{W_{\text {real }}}{W_{\text {isentropic }}}$

$\eta_{\text {Pump }}=\frac{W_{\text {isentropic }}}{W_{\text {real }}}$

The thermal efficiency of the cycle ( $\left.\eta_{\text {cycle }}\right)$ : Eq. 5 is used in the individual cycle and combined cycle.

$\eta_{\text {cycle }}=\frac{\dot{W}_{\text {net }}}{L H V_{\text {bio }} \dot{m}_{\text {bio }}+L H V_{M S W} \dot{m}_{M S W}}$

where $L H V_{\text {bio }}$ is the lower heating value biogas; $\dot{m}_{\text {bio }}$ mass flow rate biogas (engine, air heater and combustor); $L H V_{M S W}$ lower heating value municipal solid waste (MSW source); $\dot{m}_{M S W}$ mass flow rate (MSW source).

Cold gas efficiency $\left(\eta_{C G E}\right)$ :

$\eta_{C G E}=\frac{L H V_{\text {syngas }} \times \dot{V}_{\text {syngas }}}{L H V_{M S W} \times \dot{m}_{M S W}}$

where $L H V_{g a s}$ is the lower heating value syngas; $\dot{V}_{\text {syngas }}$ volume flow rate; $L H V_{\text {fuel }}$ lower heating value fuel (MSW with $10 \%$ of moisture); $\dot{m}_{M S W}$ mass flow rate (MSW with $10 \%$ of moisture). Exergetic efficiency $\left(\eta_{\text {exerg }}\right)$ :.

$\eta_{\text {exerg }}=\frac{\dot{W}_{\text {net }}}{\dot{E x}_{\text {biogas }}+\dot{E} x_{M S W}}$

Biogas exergy (Ex $\left.x_{\text {biogas }}\right)$ [16]: 


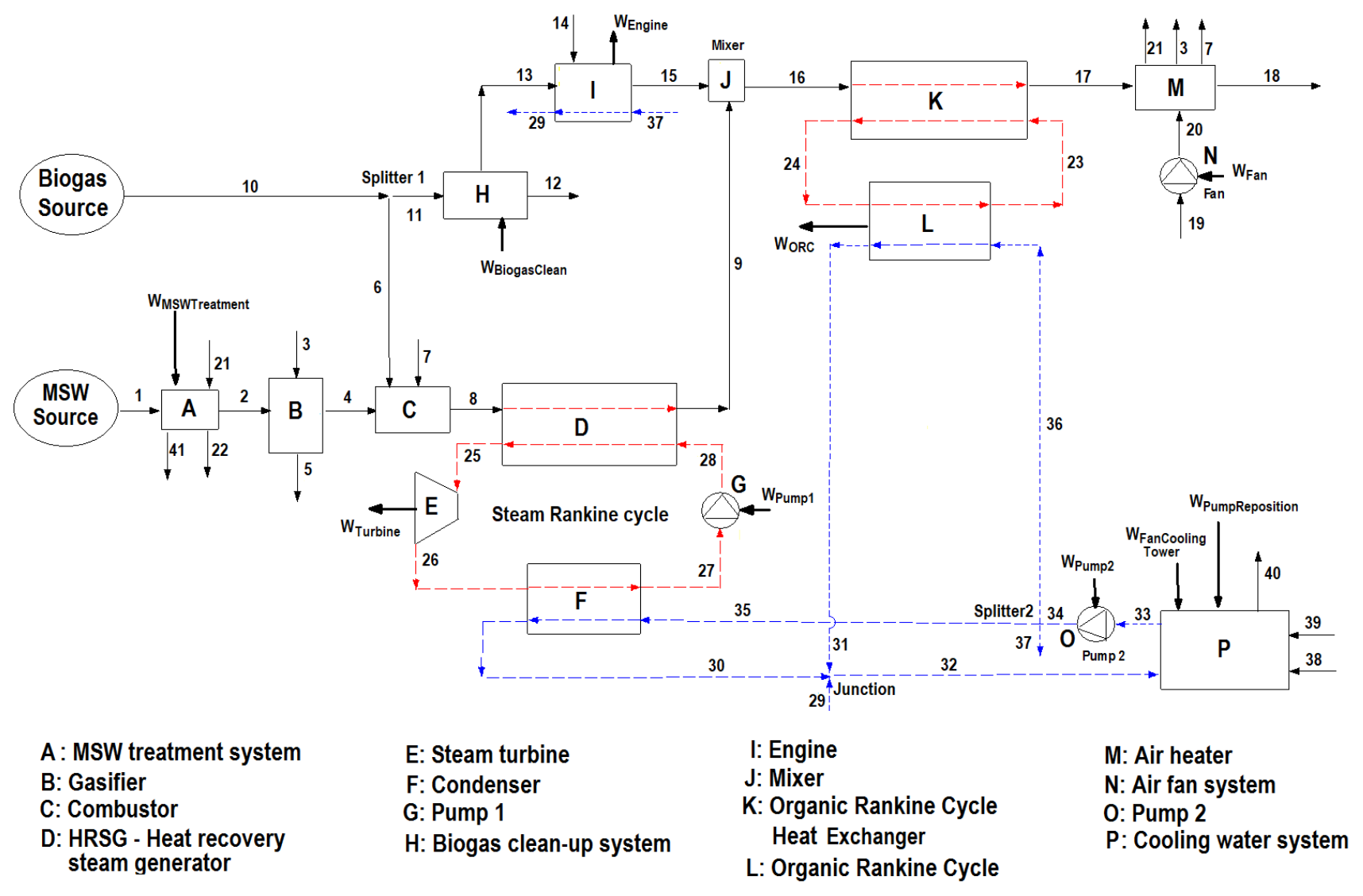

Figure 1. Combined cycles using biogas and MSW.

$\dot{E} x_{\text {biogas }}=L H V_{\text {biogas }} \times \varphi_{\text {biogas }}$

$\varphi_{\text {biogas }}=1.0334+0.0183 \frac{H}{C}-0.00694 \frac{1}{N_{C}}$

Municipal solid waste Exergy $\left(\dot{E} x_{M S W}\right)$ [17]:

$\dot{E x_{M S W}}=L H V_{M S W, \text { source }} \times \varphi_{\text {effec }}$

$\varphi_{\text {effec }}=\left(1-\frac{\omega}{1-\omega} \frac{h_{f g}}{L H V_{d m}}\right)^{-1} \varphi_{d r y}$

$\varphi_{\text {dry }}=\frac{1.0438+0.1882 \frac{\mathrm{H}}{\mathrm{C}}-0.2509 \frac{\mathrm{O}}{\mathrm{C}}\left(1+0.07256 \frac{\mathrm{H}}{\mathrm{C}}\right)+0.0383 \frac{\mathrm{N}}{\mathrm{C}}}{\left(1-0.3035 \frac{\mathrm{O}}{\mathrm{C}}\right)}$

where $\mathrm{H} / \mathrm{C}$ is the ratio of hydrogen mass to carbon mass in fuel; $\mathrm{O} / \mathrm{C}$ is the ratio of oxygen mass to carbon mass in fuel; $\mathrm{N} / \mathrm{C}$ is the ratio of nitrogen mass to carbon mass in fuel; $\mathrm{N}_{\mathrm{C}}$ mean a number of carbon atoms in the molecule of fuel.

\subsection{Municipal Solid Waste and Biogas Characteristics}

For the assessment of the proposed cycles, some hypotheses were assumed; for this study, the plant is located in the city of Santo André in Brazil. The municipality has 710,210 inhabitants and waste generation of 1.10 $\mathrm{kg} / \mathrm{capita} / \mathrm{day}$, which represents a production of $750 \mathrm{t} /$ day of waste [6]. In the simulations $96 \mathrm{t} /$ day of MSW was used representing $12.8 \%$ of the total waste generated in the city in 2016. The gravimetric composition of MSW of Santo André is shown in Table 2, and Table 3 presents the ultimate analysis and ash content (dry weight basis) [5-8]. The Lower Heating Value (LHV) is $7.86 \mathrm{MJ} / \mathrm{kg}$ (wet weight basis), calculated from $48.66 \%$ moisture content, or $17.63 \mathrm{MJ} / \mathrm{kg}$ (dry weight basis), and the heat capacity is $1171 \mathrm{~J} / \mathrm{kg} . \mathrm{K}$. On the other hand, the amount of biogas used was $35.1 \mathrm{t} /$ day $\left(1,461 \mathrm{~kg} / \mathrm{h}\right.$ or $\left.961 \mathrm{Nm}^{3} / \mathrm{h}\right)$. The main properties of biogas utilized in the simulation are presented in Table 4 [9].

Table 2. Gravimetric composition of $M S W$

\begin{tabular}{lc}
\hline Gravimetric composition & {$[\%$ weight] } \\
\hline Organic matter & $39.53 \pm 13.27$ \\
Sanitary Wastes & $10.81 \pm 4.94$ \\
Paper & $10.97 \pm 5.09$ \\
Plastics & $14.44 \pm 3.82$ \\
Textiles & $8.92 \pm 7.06$ \\
Non-combustible fraction & $15.33 \pm 10.11$ \\
Moisture & $48.66 \pm 5.04$ \\
\hline
\end{tabular}

Table 3. Ultimate analysis and ash content of MSW

\begin{tabular}{lc}
\hline Analysis & [\% weight] \\
\hline Carbon & 41.87 \\
Hydrogen & 12.25 \\
Oxygen & 28.17 \\
Nitrogen & 1.59 \\
Sulphur & 0.28 \\
Chlorine & 0.43 \\
Ash & 12.25 \\
\hline
\end{tabular}


Table 4. Biogas properties

\begin{tabular}{lc}
\hline Compound & {$[\%$ Vol] } \\
\hline $\mathrm{CH}_{4}$ & 47.69 \\
$\mathrm{CO}_{2}$ & 37.35 \\
$\mathrm{H}_{2} \mathrm{~S}$ & 0.0027 \\
$\mathrm{~N}_{2}$ & 14.89 \\
$\mathrm{H}_{2} \mathrm{O}$ & 0.0639 \\
$\mathrm{O}_{2}$ & 0.0078 \\
Temperature $\left[{ }^{\circ} \mathrm{C}\right]$ & 30 \\
Pressure $[\mathrm{kPa}]$ & 110 \\
Low Heating Value $[\mathrm{MJ} / \mathrm{kg}]$ & 13.54 \\
Low Heating Value $\left[\mathrm{MJ} / \mathrm{Nm}{ }^{3}\right]$ & 20.58 \\
\hline
\end{tabular}

\section{Numerical Simulation}

For the development of the computational program and simulation of the cycle shown in Figure 1, the Engineering Equation Solver (EES) software was used. The thermodynamic properties available in the software were used. Subprograms of the main equipment (gasifier, HRSG, ORC, engine, water cooling system) were developed in order to be called from the main EES program [10]. The hypotheses considered in the modeling of the equipment and the cycle are presented below:

Ambient conditions: Santo André city, $23^{\circ} \mathrm{C}, 92.5 \mathrm{kPa}$ and relative humidity of $55 \%$.

Thermodynamic conditions: Steady-state conditions, equilibrium at all points were considered, kinetic and potential energy variations were neglected.

Efficiency: $65 \%$ for steam turbine, $50 \%$ for pump; $45 \%$ for fan and $98 \%$ for the electric generator.

MSW treatment System (A): Specific electricity consumption is $29 \mathrm{kWh} /$ tone of MSW (separation and grinding processes), the temperature of drying air is $120^{\circ} \mathrm{C}$ (with the objective of avoiding the possibility of auto-ignition), and the output temperatures of the air and MSW are the same.

Combustion chamber (C): The temperature of the combustion chamber is $550^{\circ} \mathrm{C}$, with a pressure drop of $2 \%$ concerning the inlet pressure.

Heat recovery steam generator (D): Outlet pressure and temperature are $6.5 \mathrm{MPa}$ abs and $450^{\circ} \mathrm{C}$ respectively, the pressure drop in gas side is $250 \mathrm{mmH}_{2} \mathrm{O}(2.45 \mathrm{kPa})$, pinch point temperature difference is $10^{\circ} \mathrm{C}$, and the approach temperature difference is $10^{\circ} \mathrm{C}$.

Condenser (F): Steam side: Operation pressure is $12.3 \mathrm{kPa}$ at saturated liquid state. Water side: the temperature differential is $10^{\circ} \mathrm{C}$.

Biogas clean-up system $(\mathrm{H})$ : In this system, the water, and $\mathrm{H}_{2} \mathrm{~S}$ present in the biogas was removed. The energy consumption is $0.3 \mathrm{kWh} / \mathrm{Nm}^{3}$ of biogas entering the cleaning system [11].

Air heater (M): The pressure drop is $2 \%$ concerning the inlet pressure, the temperature of the flue gases should be higher than the dew temperature of the mixture increased in $100^{\circ} \mathrm{C}$. Flue gas temperature outside the air heater is fixed at $188^{\circ} \mathrm{C}$. Cooling water system $(\mathrm{P})$ : The temperature of the cooling water inlet is equal to $40^{\circ} \mathrm{C}$, and the cooling tower range is $10^{\circ} \mathrm{C}$. The outlet temperature of the air is $33^{\circ} \mathrm{C}$ and has $95 \%$ of relative humidity.

Engine (I): This equipment is modeled from the information presented by the engine manufacturer of the Jenbacher type 6 Biogas Engine [12]. It has the following project conditions: engine power of $1820 \mathrm{~kW}$; electricity efficiency of $44 \%$; total heat output of $1668 \mathrm{~kW}$; and exhaust stack temperature of $427^{\circ} \mathrm{C}$.

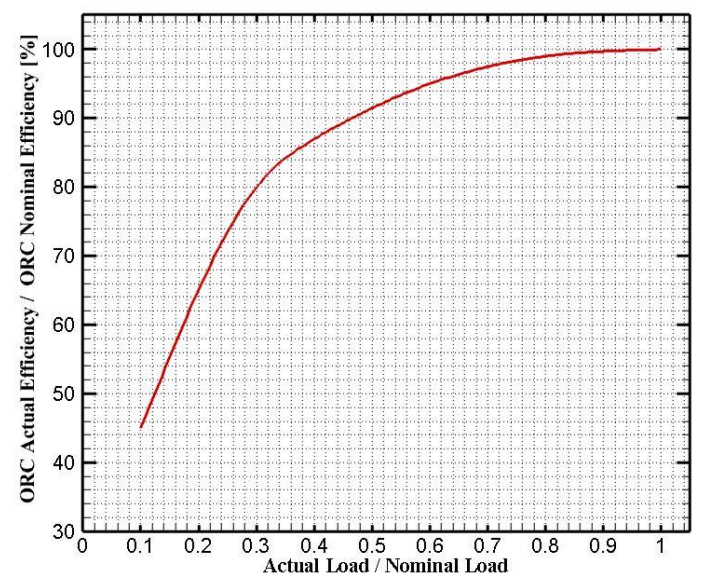

Figure 2. Turboden 6 ORC efficiency by actual load per nominal load ratio.

Organic Rankine cycle heat exchanger $(\mathrm{K})$ : Effectiveness is 0.53 and a pressure drop in gas side is equal to $2 \%$ of the inlet pressure. The heat transfer fluid used is the Therminol 55. Organic Rankine cycle (L): A parametric equation (Eq. 11), obtained from Figure 2 is presented by [13]. From Eq. 12, it is possible to estimate the efficiency of the ORC cycle ( $\eta_{\mathrm{ORC}}$ ) as a function of the thermal load available from the heat exchanger; as well as estimating the efficiency of the ORC cycle in design conditions (Eqs. 11 and 12). Eq. 11 is a function of the relation between the real load $\left(\mathrm{Q}_{\mathrm{A}}\right)$ and the load at design conditions $\left(\mathrm{Q}_{\mathrm{D}}\right)$. For the design conditions, the specifications of Turboden 6 CHP (Turboden Combined Heat \& Power) [13]: thermal efficiency of the cycle of $18.35 \%$, power of $643 \mathrm{~kW}$, and overall thermal power input of $3340 \mathrm{~kW}$ were considered. The maximum temperature of the cycle is $200^{\circ} \mathrm{C}$.

$$
\begin{aligned}
& f_{O R C}=\left[535.7 *\left(\frac{Q_{A}}{Q_{D}}\right)^{-5}-1750.7 *\left(\frac{Q_{A}}{Q_{D}}\right)^{-4}+2256.7 *\right. \\
& \left.\left(\frac{Q_{A}}{Q_{D}}\right)^{-3}-1486.8 *\left(\frac{Q_{A}}{Q_{D}}\right)^{-2}+541.8 *\left(\frac{Q_{A}}{Q_{D}}\right)+3.1861\right] * 0.01 \\
& \eta_{O R C}=f_{O R C} * \eta_{\text {Design }}
\end{aligned}
$$

Table 5. The gas composition obtained from the simulation

\begin{tabular}{ll}
\hline Compound & {$[\%$ vol] } \\
\hline $\mathrm{CH}_{4}$ & 0.0257 \\
$\mathrm{CO}_{2}$ & 0.0621 \\
$\mathrm{CO}$ & 0.2111 \\
$\mathrm{H}_{2}$ & 0.1566 \\
$\mathrm{~N}_{2}$ & 0.4313 \\
$\mathrm{H}_{2} \mathrm{O}$ & 0.0985 \\
$\mathrm{H}_{2} \mathrm{~S}$ & 0.0001 \\
$\mathrm{ClO}_{2}$ & 0.0001 \\
$\mathrm{C}_{2} \mathrm{H}_{4}$ & 0.0126 \\
$\mathrm{C}_{2} \mathrm{H}_{6}$ & 0.0020 \\
\hline
\end{tabular}

Gasifier (B): The model used for the gasification process is the chemical equilibrium model. The syngas composition is determined at the constant temperature $\left(800^{\circ} \mathrm{C}\right)$ by the equilibrium reactions using the principles of mass conservation and minimization of the Gibbs free energy. The chemical kinetic models consist of a mechanism of heat and mass transfer that, through the velocity of chemical 
reactions, determine the syngas composition as a function of time. However, given the complexity of the reactions, the number of components, and the phase inside the reactor, those models become very expensive for performing the analysis of the main parameters involved. Thus, according to Li et al. [14], chemical equilibrium models are a cheaper alternative to other models, and so, they are used in this assessment. In the equilibrium model, it is assumed that all reactions reach a steady-state condition, so, kinetic effects are not considered. Thus, in the equilibrium model, total carbon conversion and a null presence of methane are considered. To correct these differences, Li et al. [14] proposed the use of empirical correlations to consider kinetic aspects. Thus, the volume of $\mathrm{CH}_{4}$ formed and unconverted carbon are estimated using empirical correlations of [14], while the other quantities of products are found through equilibrium calculations. In this way, the empirical correlations proposed by $\mathrm{Li}$ et al. [14] are used in the program developed to simulate the gasification process. The following parameters are used in this simulation: gasification temperature of $800^{\circ} \mathrm{C}$, a gasification pressure of $7.5 \mathrm{kPa}$ (manometric), oxidant air with a temperature of $50^{\circ} \mathrm{C}$, an equivalence ratio of 0.36 , the carbon conversion efficiency of $95 \%$, and a heat loss of $2 \%$. Table 4 shows the gas composition in this condition. The LHV of the produced gas is equal to $1,891 \mathrm{~kJ} / \mathrm{Nm} 3(5,825 \mathrm{~kJ} / \mathrm{kg})$, while the cold gas efficiency is equal to $80.4 \%$.

\section{Results and Analysis}

To analyze the behavior of the cycle, simulations are performed considering the MSW moisture content and biogas to syngas ratio variations. The reference condition of moisture $48.7 \%$ and zero biogas to syngas ratio are used in the combustion chamber. Then, for each biogas to syngas ratio $(0,0.1$ and $0.2 \mathrm{~kg}$ biogas to $\mathrm{kg}$ syngas), the moisture content was set to $43.6 \%$ and $53.7 \%$. Figure 4 presents the structure used in the simulations.

Table 6 shows the main properties and the streams shown in Figure 1. The properties are obtained considering MSW moisture content $48.7 \%$ and no biogas used in the chamber (reference conditions)

Table 6. The main properties and the streams shown in Figure 1 with the reference conditions.

\begin{tabular}{|c|c|c|c|c|c|c|}
\hline $\mathrm{n}^{\circ}$ & Stream & Fluid & $\mathrm{P}[\mathrm{kPa}]$ & $\mathrm{T}\left[{ }^{\circ} \mathrm{C}\right]$ & $\mathrm{m}[\mathrm{kg} / \mathrm{s}]$ & $\mathrm{H}_{\mathrm{tot}}[\mathrm{kW}]$ \\
\hline 1 & MSW $\Rightarrow$ Dryer & MSW & 92.5 & 23.0 & 1.11 & 11167 \\
\hline 2 & Dryer $=>$ Gasifier & MSW & 92.5 & 68.8 & 0.70 & 12318 \\
\hline 3 & Air $=>$ Gasifier. & Air & 100.0 & 50.0 & 1.16 & 29 \\
\hline 4 & $\begin{array}{l}\text { Gasifier }=> \\
\text { Combustor }\end{array}$ & Syngas & 100.0 & 800.0 & 1.75 & 12087 \\
\hline 5 & $\begin{array}{l}\text { Gasifier }=> \\
\text { Ambient }\end{array}$ & Ash & 100.0 & 800.0 & 0.11 & 94 \\
\hline 6 & $\begin{array}{l}\text { Biogas }=> \\
\text { Combustor }\end{array}$ & Biogas & 100.0 & 30.0 & 0.00 & 0 \\
\hline 7 & Air $=>$ Combustor & Air & 100.0 & 50.0 & 20.04 & 504 \\
\hline 8 & $\begin{array}{l}\text { Combustor=>Boile } \\
\text { r }\end{array}$ & {$[* 1]$} & 99.0 & 550.0 & 21.78 & 12304 \\
\hline 9 & Boiler $=>$ Mixer & {$[* 1]$} & 96.6 & 166.8 & 21.78 & 3190 \\
\hline 10 & $\begin{array}{l}\text { Biogas Source => } \\
\text { Divider } 1\end{array}$ & $\begin{array}{c}\text { Bioga } \\
\mathrm{s}\end{array}$ & 100.0 & 30.0 & 0.37 & 4981 \\
\hline 11 & $\begin{array}{l}\text { Divider 1 => } \\
\text { Biogas Clean }\end{array}$ & $\begin{array}{c}\text { Bioga } \\
\mathrm{s}\end{array}$ & 100.0 & 30.0 & 0.30 & 4120 \\
\hline 12 & $\begin{array}{l}\text { Biogas Clean }=> \\
\text { Ambient }\end{array}$ & $\begin{array}{c}\mathrm{H}_{2} \mathrm{~S}+ \\
\mathrm{H}_{2} \mathrm{O}\end{array}$ & 99.0 & 25.0 & 0.00 & 0 \\
\hline 13 & $\begin{array}{l}\text { Biogas Clean }=> \\
\text { Engine }\end{array}$ & $\underset{\mathrm{s}}{\mathrm{Bioga}}$ & 99.0 & 25.0 & 0.30 & 4120 \\
\hline
\end{tabular}

Int. J. of Thermodynamics (IJoT)

\begin{tabular}{|c|c|c|c|c|c|c|}
\hline 14 & Ambient $\Rightarrow>$ Engin $\epsilon$ & Air & 92.5 & 23.0 & 2.05 & -4 \\
\hline 15 & Engine $=>$ Mixer & {$[* 1]$} & 96.6 & 427.0 & 2.36 & 2186 \\
\hline 16 & Mixer $\Rightarrow>$ ORC & {$\left[{ }^{*} 1\right]$} & 96.6 & 339.3 & 24.14 & 5376 \\
\hline 17 & ORC $=>$ Air eater & {$[* 1]$} & 94.6 & 255.0 & 24.14 & 3625 \\
\hline 18 & $\begin{array}{l}\text { Air Heat }=> \\
\text { Ambient }\end{array}$ & {$[* 1]$} & 92.7 & 190.0 & 24.14 & 2296 \\
\hline 19 & Ambient $=>$ Fan & Air & 92.5 & 23.0 & 58.44 & 2921 \\
\hline 20 & Fan $=>$ Air Heater & Air & 101.0 & 39.7 & 58.44 & 3918 \\
\hline 21 & Air Heater $\Rightarrow>$ Drye & Air & 100.0 & 120.0 & 37.24 & 5575 \\
\hline 22 & Dryer $=>$ Ambient & Air & 100.0 & 68.8 & 37.53 & 4413 \\
\hline 23 & ORC $=>$ Heater & {$[* 2]$} & 200.0 & 205.0 & 33.70 & 16948 \\
\hline 24 & Heater $\Rightarrow$ ORC & {$[* 2]$} & 200.0 & 225.0 & 33.70 & 18699 \\
\hline 25 & Boiler $\Rightarrow>$ Turbine & Steam & 6500.0 & 450.0 & 2.97 & 9773 \\
\hline 26 & $\begin{array}{l}\text { Turbine }=> \\
\text { Condenser }\end{array}$ & Steam & 12.4 & 50.0 & 2.97 & 7536 \\
\hline 27 & Condenser $=>$ Pum & Steam & 12.4 & 50.0 & 2.97 & 621 \\
\hline 28 & Pump $=>$ Boiler & Steam & 6500.0 & 51.8 & 2.97 & 660 \\
\hline 29 & Engine $=>$ Junction & Water & 112.5 & 40.0 & 34.77 & 5829 \\
\hline 30 & $\begin{array}{l}\text { Condenser }=> \\
\text { Junction }\end{array}$ & Water & 112.5 & 40.0 & $\begin{array}{c}165.4 \\
5\end{array}$ & 27734 \\
\hline 31 & ORC $=>$ Junction & Water & 112.5 & 40.0 & 34.77 & 5829 \\
\hline 32 & $\begin{array}{l}\text { Junction }=> \\
\text { Cooling Tower }\end{array}$ & Water & 112.5 & 40.0 & $\begin{array}{c}235.0 \\
0\end{array}$ & 39392 \\
\hline 33 & $\begin{array}{l}\text { Cooling Tower }=> \\
\text { Pump } 2\end{array}$ & Water & 92.5 & 30.0 & $\begin{array}{c}235.0 \\
0\end{array}$ & 29566 \\
\hline 34 & $\begin{array}{l}\text { Pump } 2 \Rightarrow \text { Divider } \\
2\end{array}$ & Water & 112.5 & 30.0 & $\begin{array}{c}235.0 \\
0\end{array}$ & 29574 \\
\hline 35 & $\begin{array}{l}\text { Divider } 2=> \\
\text { Condenser }\end{array}$ & Water & 112.5 & 30.0 & $\begin{array}{c}165.4 \\
5\end{array}$ & 20820 \\
\hline 36 & Divider $=>$ ORC & Water & 112.5 & 30.0 & 34.77 & 4376 \\
\hline 37 & Divider=> Engine & Water & 112.5 & 30.0 & 34.77 & 4376 \\
\hline 38 & $\begin{array}{l}\text { Water }=>\text { Cooling } \\
\text { Tower }\end{array}$ & Water & 100.0 & 25.0 & 3.22 & 338 \\
\hline 39 & $\begin{array}{l}\text { Ambient }=> \\
\text { Cooling Tower }\end{array}$ & Air & 92.5 & 23.0 & $\begin{array}{c}139.5 \\
8\end{array}$ & 6976 \\
\hline 40 & $\begin{array}{l}\text { Cooling Tower } \\
=>\text { Ambient }\end{array}$ & Air & 92.5 & 33.0 & $\begin{array}{c}142.8 \\
0\end{array}$ & 17140 \\
\hline 41 & $\begin{array}{l}\text { Dryer }=> \\
\text { Ambient }\end{array}$ & {$[* 3]$} & 92.5 & 68.8 & 0.13 & 10 \\
\hline 42 & $\begin{array}{l}\text { Biogas }=>\text { Air } \\
\text { Heater }\end{array}$ & $\underset{\mathrm{s}}{\mathrm{Bioga}}$ & 100.0 & 30.0 & 0.06 & 861 \\
\hline
\end{tabular}

[*1] Combustion Products; [*2] Thermal Fluid; [*3] Non-combustible faction.

As shown in Figure 4, nine simulations were performed, varying the moisture content and biogas consumption in the combustion chamber. In this way, three tables are presented, which present the main results obtained in the simulations. Table 7 shows the results obtained considering moisture of 48.7\%; Table 8 shows the results obtained considering moisture of $43.5 \%$ and Table 9 shows the results obtained considering moisture of $48 \%$.

Due to the various results presented in these tables, the analysis presented below is elaborated considering the divisions presented in tables: fuel consumption, power production, energy consumption, power consumption, and energy and emission analyses.

Fuel consumption- The ratio biogas and syngas ratio represents the relation between the biogas and syngas consumptions in the combustor, aiming for the increase of the steam production in the HRSG. It can be observed that the lower consumption of biogas in the air heater was obtained in the condition of MSW moisture $43.6 \%$ and biogas/ syngas ratio $0 \%$ (lower moisture content and lower air heating capacity for the combustor). It is the highest consumption obtained in condition MSW moisture $53.7 \%$ 


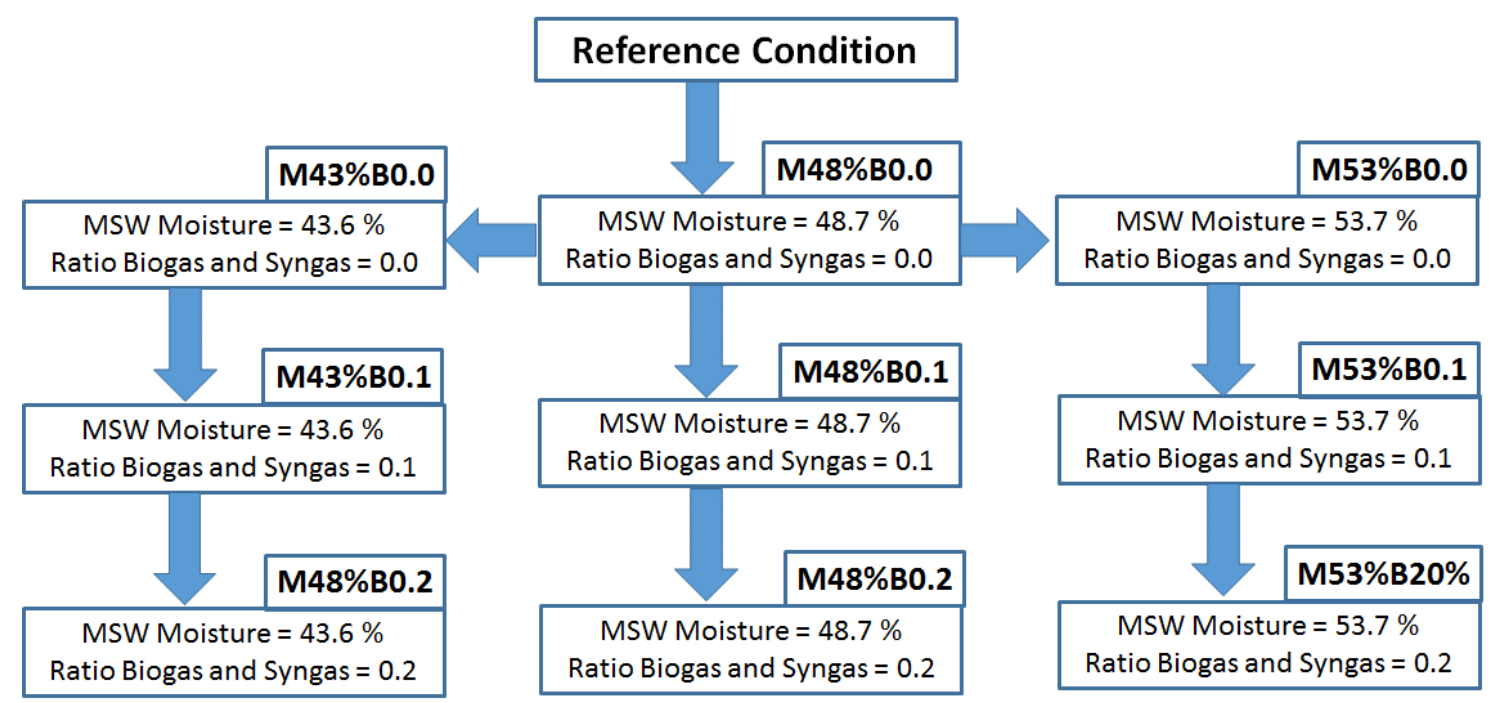

Figure 4. Combined cycles using biogas and MSW.

and biogas/ syngas ratio $20 \%$ (higher moisture content and higher air heating capacity for the combustor).

Table 7. Operation conditions: MSW moisture $48.7 \%$

\begin{tabular}{|c|c|c|c|}
\hline Ratio [kg biogas for kg syngas] & 0.0 & 0.1 & 0.2 \\
\hline Biogas Heater [kg/s] & 0.061 & 0.042 & 0.026 \\
\hline Syngas $[\mathrm{kg} / \mathrm{s}]$ & 1.75 & 1.75 & 1.75 \\
\hline Biogas combustor $[\mathrm{kg} / \mathrm{s}]$ & 0.00 & 0.17 & 0.35 \\
\hline Biogas for Engine $[\mathrm{kg} / \mathrm{s}]$ & 0.30 & 0.30 & 0.30 \\
\hline \multicolumn{4}{|l|}{ Power Production } \\
\hline Steam Rankine Cycle $[\mathrm{kW}]$ & 2193 & 2471 & 2722 \\
\hline Engine Cycle $[\mathrm{kW}]$ & 1776 & 1776 & 1776 \\
\hline Organic Rankine Cycle [kW] & 292 & 317 & 338 \\
\hline Total Power [kW] & 4261 & 4564 & 4836 \\
\hline \multicolumn{4}{|l|}{ Energy Consumption } \\
\hline MSW: Gasifier [kW] & 11167 & 11167 & 11167 \\
\hline Biogas: Engine [kW] & 4120 & 4120 & 4120 \\
\hline Biogas: Combustor [kW] & 0 & 1016 & 2031 \\
\hline Biogas: Air Heater $[\mathrm{kW}]$ & 823 & 565 & 351 \\
\hline Total $[\mathrm{kW}]$ & 16109 & 16867 & 17669 \\
\hline \multicolumn{4}{|l|}{ Power Consumption } \\
\hline Total power Pumps [kW] & -46.9 & -51.9 & -56.0 \\
\hline Fan Cooling Tower $[\mathrm{kW}]$ & -25.8 & -28.2 & -30.2 \\
\hline Fan Air Heater [kW] & -997 & -1034 & -1064 \\
\hline Biogas Clean-up [kW] & -216 & -216 & -216 \\
\hline MSW treatment [kW] & -116 & -116 & -116 \\
\hline Total consumption [kW] & -1402 & -1446 & -1482 \\
\hline \multicolumn{4}{|l|}{ Energy and Emission Analysis } \\
\hline Net Power of Engine $[\mathrm{kW}]$ & 1560 & 1560 & 1560 \\
\hline Engine Efficiency [\%] & 37.86 & 37.86 & 37.86 \\
\hline Net Power of Rankine [kW] & 1013 & 1247 & 1463 \\
\hline Rankine Efficiency [\%] & 9.07 & 11.17 & 13.10 \\
\hline ORC Power [kW] & 286 & 311 & 331 \\
\hline ORC Efficiency [\%] & 17.02 & 17.25 & 17.43 \\
\hline Total Net Power [kW] & 2859 & 3118 & 3354 \\
\hline Total Efficiency-LHV [\%] & 17.75 & 18.49 & 18.98 \\
\hline Total Efficiency-HHV [\%] & 16.86 & 17.60 & 18.11 \\
\hline Exergy Efficiency [\%] & 14.59 & 15.27 & 15.75 \\
\hline Avoided $\mathrm{CH}_{4}$ emission $[\mathrm{g} / \mathrm{kWh}]$ & 99 & 91 & 84 \\
\hline $\mathrm{CO}_{2}$ emissions $[\mathrm{g} / \mathrm{kWh}]$ & 1855 & 1969 & 2079 \\
\hline Water consumption $\left[\mathrm{m}^{3} / \mathrm{h}\right]$ & 3.22 & 3.52 & 3.77 \\
\hline
\end{tabular}

Power production-The individual power of each cycle (Steam Rankine Cycle, Engine Cycle, and Organic Rankine Cycle), and their participation in the total power supplied by the Combined Cycle; are presented. It was observed that the amount of MSW was sufficient to supply energy demand in all simulated condition, in the reference condition, the total power produced by the steam cycle was close to the total power produced by the Engine Cycle.
Table 8. Operation conditions: MSW moisture $43.6 \%$

\begin{tabular}{lccc}
\hline Ratio [kg biogas for kg syngas] & 0.0 & 0.1 & 0.2 \\
\hline Biogas Heater [kg/s] & 0.035 & 0.016 & 0.000 \\
Syngas [kg/s] & 1.81 & 1.81 & 1.81 \\
Biogas combustor [kg/s] & 0.00 & 0.18 & 0.36 \\
Biogas for Engine [kg/s] & 0.30 & 0.30 & 0.30 \\
\hline Power Production & & & \\
\hline Steam Rankine Cycle [kW] & 2283 & 2568 & 2829 \\
Engine Cycle [kW] & 1776 & 1776 & 1776 \\
Organic Rankine Cycle [kW] & 301 & 325 & 346 \\
Total Power [kW] & 4360 & 4670 & 4951 \\
\hline Energy Consumption & & & \\
\hline MSW: Gasifier [kW] & 12263 & 12263 & 12263 \\
Biogas: Engine [kW] & 4120 & 4120 & 4120 \\
Biogas: Combustor [kW] & 0 & 1052 & 2103 \\
Biogas: Air Heater [kW] & 470 & 212 & 0 \\
Total [kW] & 16853 & 17647 & 18486 \\
\hline Power Consumption & & & \\
\hline Total power Pumps [kW] & -48.5 & -53.5 & -57.7 \\
Fan Cooling Tower [kW] & -26.6 & -29.0 & -30.9 \\
Fan Air Heater [kW] & -956 & -992 & -1022 \\
Biogas Clean-up [kW] & -216 & -216 & -216 \\
MSW treatment [kW] & -104 & -104 & -104 \\
Total consumption [kW] & -1351 & -1395 & -1431 \\
\hline Energy and Emission Analysis & & & \\
\hline Net Power of Engine [kW] & 1560 & 1560 & 1560 \\
PEngine Efficiency [\%] & 37.86 & 37.86 & 37.86 \\
Net Power of Rankine [kW] & 1155 & 1396 & 1621 \\
Rankine Efficiency [\%] & 9.41 & 11.38 & 13.22 \\
ORC Power [kW] & 295 & 319 & 339 \\
ORC Efficiency [\%] & 17.10 & 17.33 & 17.50 \\
Total Net Power [kW] & 3009 & 3275 & 3520 \\
Total Efficiency-LHV [\%] & 17.85 & 18.56 & 19.04 \\
Total Efficiency-HHV [\%] & 16.92 & 17.63 & 18.13 \\
Exergy Efficiency [\%] & 14.87 & 15.52 & 15.99 \\
Avoided CH ${ }_{4}$ emission [g/kWh] & 97 & 90 & 83 \\
CO ${ }_{2}$ emissions [g/kWh] & 1808 & 1924 & 2036 \\
Water consumption [m $\left.{ }^{3} / \mathrm{h}\right]$ & 3.32 & 3.62 & 3.86 \\
\hline & & \\
\hline
\end{tabular}

Energy consumption-The energy consumed in each cycle, for the presented conditions, is displayed in Tables 7, 8 and 9. It should be noted that the MSW consumption was set at $96 \mathrm{t} /$ day $(4 \mathrm{t} / \mathrm{h})$ however the useful energy varies due to the influence of the moisture on the heating value.

Power consumption-The power consumption for driving the equipment necessary for the operation of the power cycles is highlighted. It should be noted that some of the equipment is commonly used in all cycles (Fan cooling tower, and pumps), while there is the equipment of specific use in the Engine cycle (biogas clean-up), and the Steam Rankine Cycle (pump1, fan air heater, MSW treatment). 
These consumptions influenced the individual net power of each cycle so that it is possible to identify their participation in the total net power of the Combined Cycle. The power consumption represents $31.5 \%$ (MSW moisture $43.6 \%$ and $0 \mathrm{~kg}$ biogas to $\mathrm{kg}$ syngas) to $35.7 \%$ (MSW moisture $53.7 \%$ and $0.2 \mathrm{~kg}$ biogas to $\mathrm{kg}$ syngas) of the total power production of each simulation.

Table 9. Operation conditions: MSW moisture $53.7 \%$

\begin{tabular}{|c|c|c|c|}
\hline Ratio [kg biogas for kg syngas] & 0.0 & 0.1 & 0.2 \\
\hline Biogas Heater [kg/s] & 0.087 & 0.068 & 0.052 \\
\hline Syngas $[\mathrm{kg} / \mathrm{s}]$ & 1.69 & 1.69 & 1.69 \\
\hline Biogas combustor $[\mathrm{kg} / \mathrm{s}]$ & 0.00 & 0.17 & 0.34 \\
\hline Biogas for Engine [kg/s] & 0.30 & 0.30 & 0.30 \\
\hline \multicolumn{4}{|l|}{ Power Production } \\
\hline Steam Rankine Cycle [kW] & 2108 & 2381 & 2625 \\
\hline Engine Cycle [kW] & 1776 & 1776 & 1776 \\
\hline Organic Rankine Cycle [kW] & 284 & 309 & 330 \\
\hline Total Power $[\mathrm{kW}]$ & 4168 & 4466 & 4731 \\
\hline \multicolumn{4}{|l|}{ Energy Consumption } \\
\hline MSW: Gasifier [kW] & 10055 & 10055 & 10055 \\
\hline Biogas: Engine [kW] & 4120 & 4120 & 4120 \\
\hline Biogas: Combustor [kW] & 0 & 982 & 1963 \\
\hline Biogas: Air Heater [kW] & 1174 & 917 & 702 \\
\hline Total $[\mathrm{kW}]$ & 15349 & 16073 & 16840 \\
\hline \multicolumn{4}{|l|}{ Power Consumption } \\
\hline Total power Pumps [kW] & -45.3 & -50.3 & -54.5 \\
\hline Fan Cooling Tower [kW] & -25.1 & -27.5 & -29.4 \\
\hline Fan Air Heater [kW] & -1040 & -1077 & -1107 \\
\hline Biogas Clean-up [kW] & -216 & -216 & -216 \\
\hline MSW treatment $[\mathrm{kW}]$ & -129 & -129 & -129 \\
\hline Total consumption $[\mathrm{kW}]$ & -1455 & -1499 & -1535 \\
\hline \multicolumn{4}{|l|}{ Energy and Emission Analysis } \\
\hline Net Power of Engine [kW] & 1560 & 1560 & 1560 \\
\hline Engine Efficiency [\%] & 37.86 & 37.86 & 37.86 \\
\hline Net Power of Rankine [kW] & 875 & 1104 & 1313 \\
\hline Rankine Efficiency [\%] & 8.70 & 10.98 & 13.05 \\
\hline ORC Power [kW] & 278 & 303 & 323 \\
\hline ORC Efficiency [\%] & 16.94 & 17.18 & 17.37 \\
\hline Total Net Power $[\mathrm{kW}]$ & 2713 & 2967 & 3195 \\
\hline Total Efficiency-LHV [\%] & 17.68 & 18.46 & 18.98 \\
\hline Total Efficiency-HHV [\%] & 16.84 & 17.62 & 18.15 \\
\hline Exergy Efficiency [\%] & 14.30 & 15.02 & 15.52 \\
\hline Avoided $\mathrm{CH}_{4}$ emission $[\mathrm{g} / \mathrm{kWh}]$ & 101 & 92 & 86 \\
\hline $\mathrm{CO}_{2}$ emissions $[\mathrm{g} / \mathrm{kWh}]$ & 1908 & 2017 & 2125 \\
\hline Water consumption $\left[\mathrm{m}^{3} / \mathrm{h}\right]$ & 3.13 & 3.43 & 3.67 \\
\hline
\end{tabular}

Energy and emission analysis- The net power and the efficiency of the Engine Cycle are fixed since there was no variation in neither the biogas consumption nor the heating value. The average participation of the engine cycle in the total power of the Combined Cycle was 50.4\%, the participation of Steam Rankine Cycle was $43.7 \%$, and participation of the Organic Rankine Cycle was 5.9\%. In the Steam Rankine cycle, they are owing to the high consumption of auxiliaries, the variation of the heating value, and the biogas consumption in the combustion.

Figure 5 presents the net power production in each condition $(48.7 \%, 43.7 \%$, and $53.7 \%$ of moisture content). The lines show consumption of $0 \%$ of biogas in chamber combustion. This line is $10 \%$ of biogas in chamber combustion, and this line is $20 \%$ of biogas in chamber combustion. The highest values of net power are obtained when $20 \%$ of biogas is used. It is possible to observe that with less moisture content, more power was obtained, and the influence of the use of biogas in the combustion chamber is minimum. But with high moisture, we observe the inverse. Analyzing the results of the Combined Cycle, the highest total net power was obtained with a moisture of $43.6 \%$ and a biogas/syngas ratio of $0.2(3520 \mathrm{~kW})$; while the lowest value was obtained with a moisture of $53.7 \%$ and a biogas/ syngas ratio of $0.0(2713 \mathrm{~kW})$.

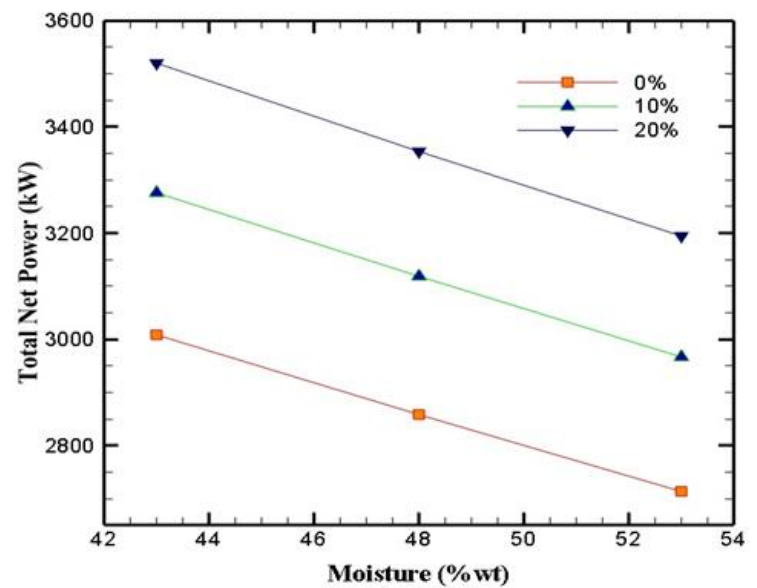

Figure 5. Net Power production obtained for each condition of moisture content.

Figure 6 presents the exergy efficiency in each condition, it is possible to observe the maximum efficiency was obtained when biogas is used in the combustion chamber. It can be observed that the highest efficiencies occur using biogas in the combustor, and not in the simulations without the use of biogas $(0 \%)$. This was due to the need to use additional biogas in the air heater (see Tables 6, 7 and 8) to maintain the temperature in the gases at the exit of the air heater (point 18) equal to $188^{\circ} \mathrm{C}$. It should be noted that in the condition MSW moisture of $43.6 \%$ and biogas/syngas ratio of 0.2 , the consumption of biogas in the air heater was zero, such that for all other operating conditions it was necessary to use biogas in the heater.

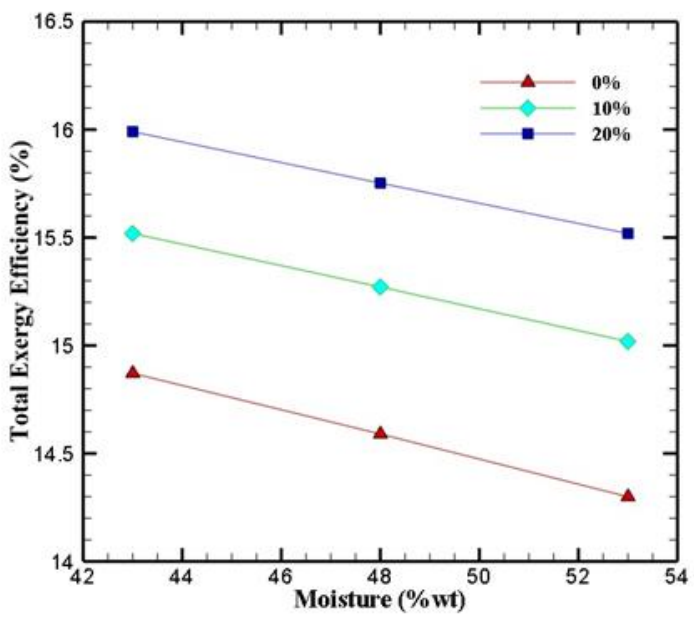

Figure 6. Exergy Efficiency obtained for each condition of moisture content.

Figure 7 shows the average amount of $\mathrm{CO}_{2}$ emitted with no biogas consumption is 1,634 grams per kilowatt hour ( $\mathrm{g} / \mathrm{kWh}$ ), with $10 \%$ of biogas consumption is 1,875 grams per kilowatt hour $(\mathrm{g} / \mathrm{kWh})$, and with $20 \%$ of biogas consumption is 2,117 grams per kilowatt hour $(\mathrm{g} / \mathrm{kWh})$. It can be seen that only the biogas per syngas ratio influences the emissions.

Concerning the methane avoided, it can be observed that the highest values were obtained in the simulations that did not use biogas in the combustor (Figure 8). As this indicator is a function of the power produced, the highest values were obtained with humidity of $53.7 \%$ presented higher indicators because they presented lower power produced about the other humidities (43.6 and 48.7\%). It should be noted that 1 $\mathrm{g}$ of $\mathrm{CH}_{4}$ is equivalent to $21 \mathrm{~g}$ of $\mathrm{CO}_{2}$ (Global Warming 
Potential-GWP) [15], in this way, the displayed values of $\mathrm{CH}_{4}$ avoided are equivalent to the levels of $\mathrm{CO}_{2}$ emitted, that is to say, presenting a considered reduction of emissions of greenhouse gases.

Analysing the amount of water consumed by the cooling system, it can be a problem if there is no water available in the place where the plant is installed. The use of dry cooling towers is an alternative that presents, practically, no water consumption. However, they show higher electrical energy consumption, besides being operated at a higher condensing temperature; when comparing them to wet towers considering the same atmospheric air conditions.

It should be noted that the use of the Motor Cycle, Rankine Cycle and Organic Rankine Cycle operating in the Combined Cycle, allows the use of energy more efficiently, and thus, there is a better use of the available energy in the fuels. Also, this configuration provides flexibility in the generation of energy due to the use of biogas in the HRSG combustor, in addition to maintaining a stable generation of energy in the steam cycle, even when the moisture content of urban solid waste increases. It should be noted that this flexibility is linked to the availability of biogas in the plant i.e. there may be limitations on the use of biogas throughout the life of the landfill and also biogas not produced due to the solid urban waste not deposited in the landfill. When this occurs we need to perform an analysis of how best to use the biogas, use on the cycle or the combustor.

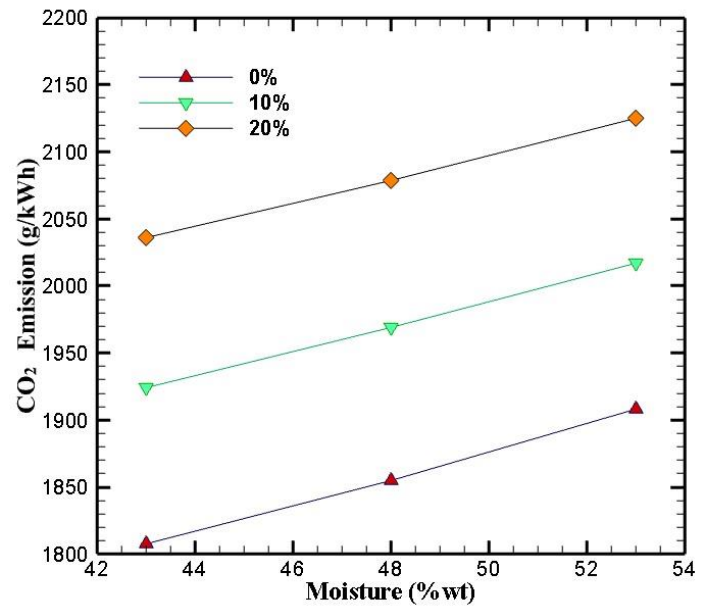

Figure 7. $\mathrm{CO}_{2}$ emission obtained for each condition of moisture content.

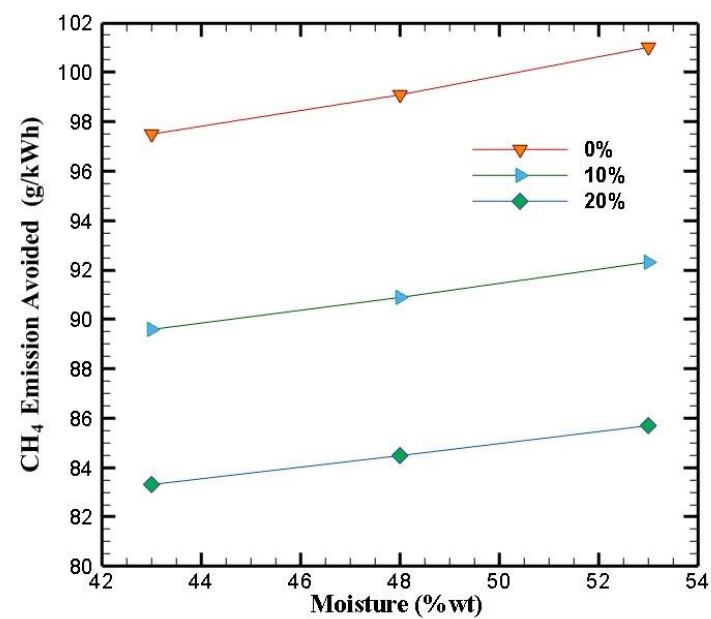

Figure 8. $\mathrm{CH}_{4}$ emission avoided obtained for each condition of moisture content.

\section{Conclusions}

The average value of the exergetic efficiency was $15.2 \%$ and $3,112 \mathrm{~kW}$ of total net power for the combined cycle. The net power and the efficiency of the Engine cycle were fixed since there was no variation either in the biogas consumption or in its heating value. The participation of the engine cycle in the total power of the Combined Cycle was $39.1 \%$. In the case of the Steam Rankine cycle, owing to the high consumption of auxiliaries, the variation of the heating value, and the biogas consumption in the combustion, the average participation of this cycle in the total power of the Combined Cycle was $53.9 \%$, with an average efficiency of $11.1 \%$. The ORC cycle contributed, on average, in $6.9 \%$ to the total power, presenting an average efficiency of $17.2 \%$. The average amount of $\mathrm{CO}_{2}$ emitted obtained in the simulation was $1,969 \mathrm{~g} / \mathrm{kWh}$. Regarding the avoided $\mathrm{CH}_{4}$ emissions, an average of $91.5 \mathrm{~g} / \mathrm{kWh}$ was obtained. It should also be noticed that the use of the Engine Cycle, Steam Rankine Cycle and Organic Rankine Cycle operating in the Combined Cycle, enables greater flexibility concerning power generation and efficient and proper use of the available energy in the fuel.

\section{Acknowledgments}

The authors would like to acknowledge Petrobrás for the financial support to the project "Estudo da geração em Ciclo Combinado a partir de biogás e resíduos sólidos" (TCTC 0050.0084633.13.9).

Nomenclature

CHP Turboden Combined Heat \& Power

EES Engineering Equation Solver

h Specific enthalpy $[\mathrm{kJ} / \mathrm{kg}]$.

HRSG Heat Recovery Steam Generator

Le Level above the sea [m]

LHV Lower heating value

$\dot{m} \quad$ Mass flow rate $[\mathrm{kg} / \mathrm{s}]$

MSW Municipal solid waste

ORC Organic Rankine Cycle

$\dot{Q}_{K} \quad$ Thermal energy rate $[\mathrm{kW}]$

$\mathrm{Q}_{\mathrm{D}} \quad$ ORC power at design conditions [kW]

$\mathrm{Q}_{\mathrm{A}} \quad$ Actual power $[\mathrm{kW}]$

$\mathrm{T}_{\text {Lo }} \quad$ Local temperature $\left[{ }^{\circ} \mathrm{C}\right]$.

SRC Steam Rankine Cycle

WTE Waste-to-Energy

$\dot{W}_{\text {pump }}$ Pump power $[\mathrm{kW}]$

列C Efficiency of the ORC cycle [\%]

$\mathrm{W}_{\text {corr }}$ Engine power actual $[\mathrm{kW}]$

$\mathrm{W}_{\text {Desig }}$ Engine power design condition [kW]

$\mathrm{f}_{\text {level }} \quad$ Correction factor due to ambient temperature

$\mathrm{f}_{\text {Temp }} \quad$ Correction factor due to ambient pressure

$\mathrm{Q}_{\mathrm{A}} \quad$ ORC Real thermal load [kW]

QD ORC design condition thermal load [kW]

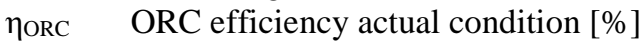

$f_{\text {ORC }} \quad$ Correction factor due to thermal load

ךoRC.D ORC efficiency design condition [\%]

\section{Greek symbols}

$\eta \quad$ Efficiency

\section{Subscripts and superscripts}

h Hot fluid

c Cold fluid

i State point or equipment index i 


\section{References}

[1] Environmental Protection Agency (EPA); Technology Characterization: Reciprocating Engines. Available in: http://www.epa.gov/chp/documents/catalog_chptech_re ciprocating_engines.pdf. [accessed 01.12.2013].

[2] A.L. Marchezetti, E. Kaviski,M. C. B. Braga, “Aplicação do método AHP para a hierarquização das alternativas de tratamento de resíduos sólidos domiciliares" Ambiente Construido, Porto Alegre. 11, 173-187, 2011.

[3] M. Korobitsyn, P. Jellema, G. Hirs, "Possibilities for gas turbine and waste incinerator integration". Energy, 24, 783-793. 1999.

[4] M. He, Z. Hu, B. Xiao, J. Li, X. Guo, S. Luo, F. Yang, Y. Feng, G. Yang, S. Liu, "Hydrogen-rich gas from catalytic steam gasification of municipal solid waste (MSW): Influence of catalyst and temperature on yield and product composition". International Journal of Hydrogen Energy 34, 195-203. 2009.

[5] R. Eisted, T. H. Chrestensen, "Characterization of household waste in Greenland". Waste Management, 31, 1461-1466. 2011.

[6] A. C. Gutierrez-Gomez (2016). Caracterização da fração combustivel de Resíduos Sólidos Urbanos úmidos do município de Santo André visando seu aproveitamento energético por processos termoquímicos. 90p. Dissertation (Master in EnergyCentre of Engineering. Modelling and Social Sciences. Post-graduation in Energy. Federal University of ABC).

[7] D. Komilism, A. Evangelou, G. Giannkis, C. Lympeis, Revisiting the elemental composition and the calorific value of the organic fraction of municipal solid wastes. Waste Management. 32, 372-381. 2012.

[8] A. Semasa, Caracterização gravimétrica dos resíduos sólidos urbanos domiciliares do munícipio de Santo André. Santo André: Prefeitura de Santo André. 2008

[9] Lara Central de Tratamento de Resíduos "Estimativa de emissões atmosférica dos queimadores de biogás do aterro Lara”. São Bernardo do Campo. 2013.

[10] A. Gallego, R. Tartari. "Engine Behavior Analysis Using Biogas". CILAMCE 2015. Proceedings of the XXXVI Iberian Latin-American Congress on Computational Methods in Engineering Ney Augusto Dumont (Editor). ABMEC. Rio de Janeiro. RJ. Brazil. Nov.22-25. 2015.

[11] F. Baur, C. Hulteberg, T. Persson, D. Tamm, "Biogas upgrading - review of commercial technologies. Swedish Gas Technology Centre". 2013. - Available at:http://www.sgc.se/ckfinder/userfiles/files/SGC270.pd f [accessed 28.01.2018].

[12] GE Power. Jenbacher type: Gas Engine Technical Data.https://www.gepower.com/content/dam/gepowerpgdp/global/en_US/documents/product/Reciprocating\% 20Engines/Jenbacher/Type\%206/jenbacher-type-6-fsen-metric-2016.pdf [acessed: 04.04.2017].

[13] Turboden. Organic Rankine Cycle Technology. Brescia. https://www.turboden.com/ [accessed 25.05.2018].

[14] X. Li, J. R. Grace, C. J. Lim, J. R. Watkinson, H. P. Chen, J. R. Kim, "Biomass Gasification in a Circulating Fluidized Bed". Biomass and Bioenergy, 26, 171-193. 2004.

[15] Intergovernmental panel on Climate Chande (IPCC) Climate Change 2007: Working Group I: The Physical Science Basis.

https://www.ipcc.ch/publications_and_data/ar4/wg1/en/ ch2s2-10-2.html [accessed 10.01.2018]

[16] J. Szargut, D. R. Morris, F. R. Stwart. Exergy analysis of thermal, chemical and metallurgical process. Hemisphere Publ. Corp, New York, 1988.

[17] I. S. Ertesvag, Energy and exergy in moist fuels. Department of Energy and Process Engineering, NTU, 2000. http://folk.ntnu.no/ivarse/energi/moistfuel.pdf. [accessed 28.01.2018]. 